precisa que mais jovens pertençam formalmente ao Grupo. O aumento do número de sócios (< 35 anos) pertencentes ao GQJ levará a um enriquecimento da discussão sobre as actividades do Grupo e sobre a sua continui- dade no futuro. Para oficializares a tua adesão ao GQJ envia um fax (+351 217952349) ou email (sede@spq.pt) indicando o teu nome, $n^{\circ}$ de sócio da $S P Q$ e a intenção de pertenceres ao GQJ.
Contamos com a tua visita e participação!

Grupo de Químicos Jovens Carlos Baleizão, Frederico Ferreira, Pedro Gois

\title{
Prémıo Químicos Jovens 2010 / Portuguese Young Chemists Award 2010
}

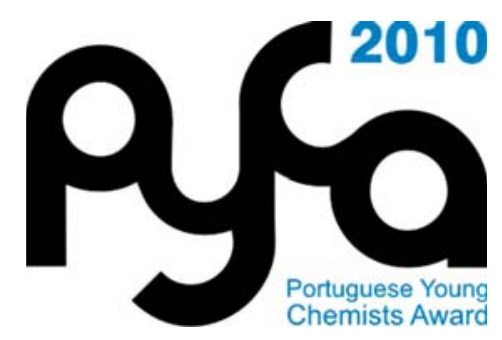

O Grupo de Químicos Jovens tem o prazer de anunciar a primeira edição do Prémio Químicos Jovens / Portuguese Young Chemists Award.

Este prémio visa promover a excelência da Química desenvolvida por Jovens Investigadores, com especial enfoque na divulgação e impacto desta disciplina na Sociedade. Com esta iniciativa, o Grupo de Químicos Jovens (GQJ) pretende dinamizar e consciencializar os jovens químicos para a importância de divulgar ciência, com enfoque na Química.

O prémio destina-se a recém-doutorados em Química e áreas afins que cumpram cumulativamente as seguintes condições:

x Tenham nacionalidade Portuguesa ou, caso tenham outra nacionalidade, tenham obtido o grau de doutoramento numa Universidade Portuguesa.

x Tenham menos de 35 anos a 31 de Dezembro de 2009.

x Tenham obtido o grau de doutor entre 1 de Janeiro de 2008 e 31 de Dezembro de 2009.

× Sejam sócio da SPQ com quotas regularizadas.
O júri será constituído pelo Professor Jorge Morgado do Instituto Superior Técnico e Editor do Boletim da Sociedade Portuguesa de Química (SPQ), pelo Professor Eurico Cabrita da Faculdade de Ciências e Tecnologia da Universidade Nova de Lisboa e pela Doutora Mónica Bettencourt Dias do Instituto Gulbenkian de Ciência.

A avaliação terá como base a qualidade de um artigo de divulgação científica elaborado pelo candidato a partir do trabalho desenvolvido no seu doutoramento, tendo em conta o impacto do trabalho exposto e a capacidade de comunicação com a sociedade.

O prémio será entregue no " $2^{\text {nd }}$ Portuguese Young Chemists Meeting" (2PYCheM), que se realizará em Abril de 2010 em Aveiro.

O candidato vencedor, para além de ver o seu artigo publicado no Boletim da SPQ, receberá a oferta de um ano de quotas da SPQ. O candidato distinguido terá ainda a possibilidade de apresentar uma comunicação oral (Comunicação Oral convidada) no

\section{Datas Importantes}

Prazo para envio de candidaturas: 1 a 31 de Janeiro de 2010 Divulgação dos resultados aos candidatos: 15 de Março de 2010 Entrega do prémio: $21-23$ de Abril de 2010, $2^{\text {nd }}$ Portuguese Young Chemists Meeting decorrer do 2PYCheM, sob a mesma temática do seu artigo vencedor. O júri poderá atribuir Menções Honrosas, premiando outras candidaturas que se tenham destacado, e que se traduzirão na publicação dos respectivos artigos no Boletim da SPQ.

Os jovens químicos que tenham a intenção de se candidatar podem obter mais detalhes através do "Regulamento Geral" e do "Regulamento PYCA 2010" disponíveis na página do GQJ em www.spq.pt/gqj

\section{Contamos com a tua participação}

Grupo de Químicos Jovens

Carlos Baleizão, Frederico Ferreira, Pedro Gois

Esteja sempre actualizado e saiba o que se passa no mundo da Química com o nosso Boletim trimestral. Vá a www.spq.pł e torne-se sócio. 


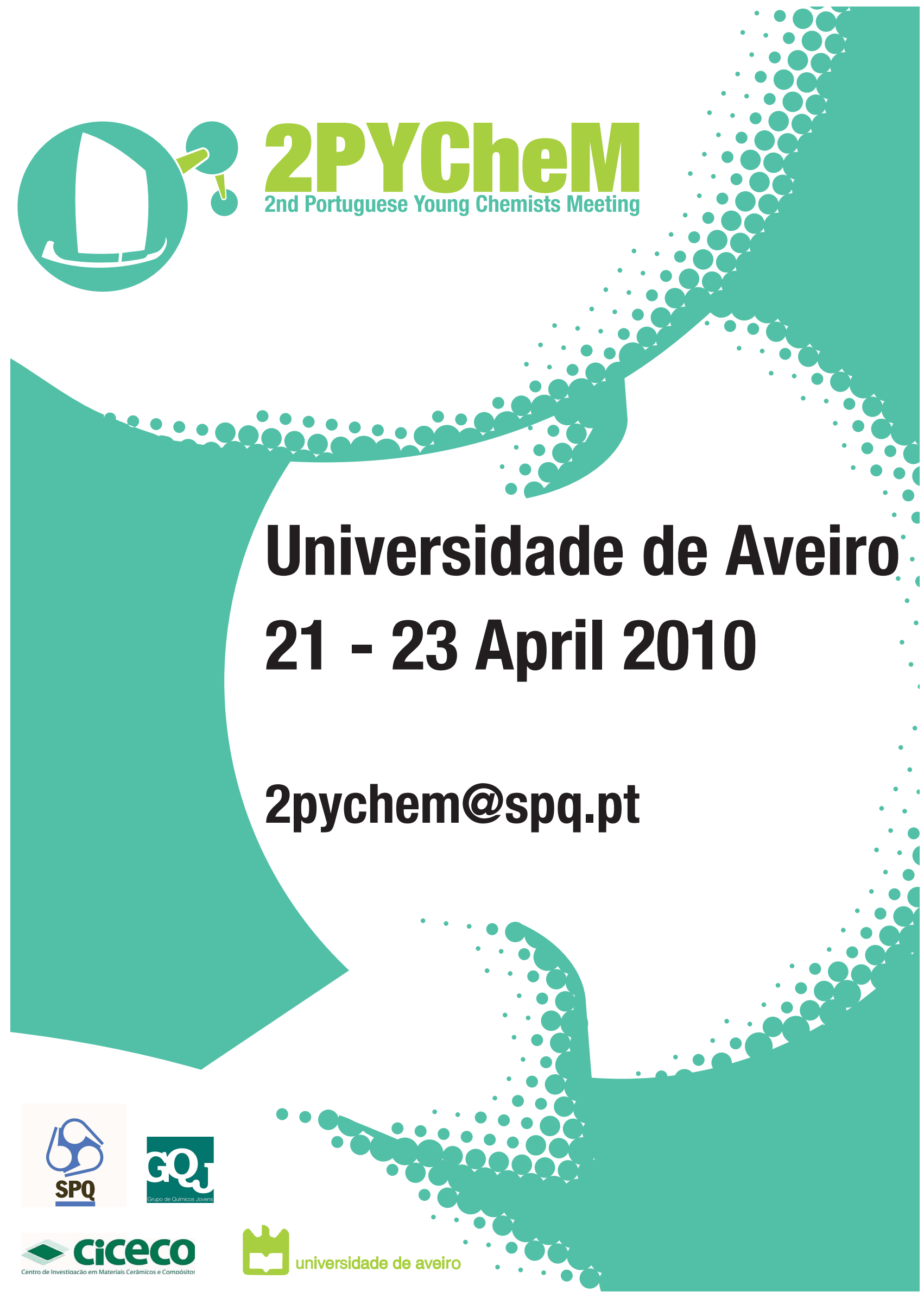

